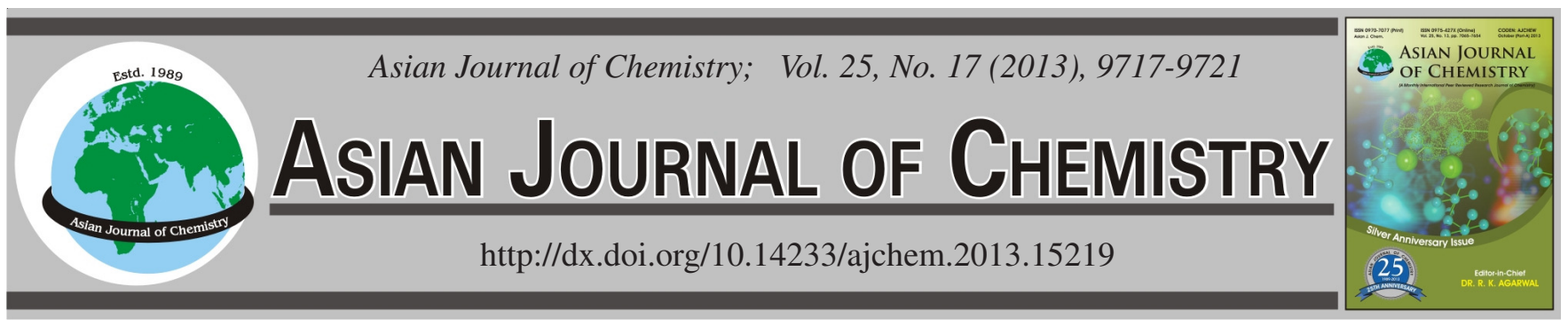

\title{
Estimation of Naproxen Related Substances in Sumatriptan Succinate and Naproxen Sodium Tablets by UPLC
}

\author{
Palavai Sripal Reddy ${ }^{1,2, *}$, Shakil Sait $^{1}$ and Kishore Kumar Hotha ${ }^{1}$
}

${ }^{1}$ Dr. Reddy's Laboratories Ltd. IPDO, Bachupally, Hyderabad-500 072, India

${ }^{2}$ Department of chemistry, Jawaharlal Nehru Technological University, Kukuatpally, Hyderabad-500 0085, India

*Corresponding author: Fax: +91 40 44346285; Tel: +91 40 44346148; E-mail: sripalrp@ drreddys.com

\begin{abstract}
A novel isocratic reverse phase ultra performance liquid chromatographic method was developed and validated for quantitative determination of naproxen sodium and its four impurities in sumatriptan and naproxen sodium tablets. Chromatographic separation was achieved on Acquity $\mathrm{CSH} \mathrm{C}_{18} 100 \mathrm{~mm} \times 2.1 \mathrm{~mm}, 1.7 \mu \mathrm{m}$ with mobile phase milli-Q Water, acetonitrile and glacial acetic acid in the ratio of 50:50:1 $(\mathrm{v} / \mathrm{v} / \mathrm{v})$. The flow rate of the mobile phase was $0.5 \mathrm{~mL} / \mathrm{min}$ naproxen and its impurities were monitored at $260 \mathrm{~nm}$ wavelength. The total run time was 10 min with in which all the impurities were well separated from naproxen sodium. Naproxen sodium was found to degrade significantly in acid and oxidative stress conditions and stable in base, water and photolytic stress conditions. The degradation products were well resolved from main peak. The developed method was validated as per ICH guidelines.
\end{abstract}

Key Words: Development, UPLC, Naproxen sodium, Sumatriptan succinate, Impurities, LC-MS/MS.

\section{INTRODUCTION}

Naproxen sodium (NAS) is a non-steroidal antiinflammatory drug used to relieve moderate to severe aches and pains ${ }^{1-3}$. Most of its therapeutic activity is probably mediated through prostaglandin synthesis inhibition ${ }^{4}$. Naproxen $[(+)-$ 2-(6-methoxy-2-naphthyl)propionic acid (NAP), is a nonsteroidal antiinflammatory drug with antiinflammatory, analgesic and antipyretic properties often preferred to acetylsalicylic acid (aspirin) because of its better absorption following oral administration and fewer adverse effects. The empirical formula is $\mathrm{C}_{14} \mathrm{H}_{13} \mathrm{NaO}_{3}$, with a molecular weight of 252.23 . Naproxen sodium is a white-to-creamy white crystalline solid, freely soluble in water at neutral $\mathrm{pH}$. Once dissolved in biological fluids, naproxen and naproxen sodium are chemically identical species and have the same biological properties. Administration of naproxen as the sodium salt, however, permits more rapid absorption from the gastrointestinal tract $t^{5,6}$. Peak plasma concentration is reached in 1-2 $\mathrm{h}$ after ingestion of the sodium salt ${ }^{7,8}$. Food reduces the rate but not the extent of absorption. Naproxen sodium is chemically 1-(2S)-2-(6methoxynaphthalen-2-yl)propanoic acid, used as antiinflammatory drug (NSAID). Sumatriptan, a 5-HT1 receptor agonist that mediates vasoconstriction of the human basilar artery and vasculature of human dura mater, which correlates with the relief of migraine headache. It also contains naproxen, an NSAID that inhibits the synthesis of inflammatory mediators. Therefore, sumatriptan and naproxen contribute to the relief of migraine through pharmacologically different mechanisms of action. Naproxen in commercial formulations has been determined by coulometer ${ }^{9}$, UV spectrophotometer, heavy atom-induced room temperature phosphorescence and highperformance liquid chromatography (HPLC) ${ }^{10-15}$. Literature survey reveals a few analytical techniques like UV, HPLC, HPTLC and LC-MS are reported for naproxen in combination with other drugs ${ }^{16-22}$. But no literature on estimation of naproxen sodium and its related impurities in combination tablet dosage forms by UPLC method. The proposed method was validated as per the ICH guidelines.

\section{EXPERIMENTAL}

Naproxen sodium standards and samples were supplied by Dr. Reddy's Laboratories Limited, IPDO and Hyderabad, India. Commercially available Treximet ${ }^{\mathrm{TM}}$ was used for the dosage form analysis. HPLC grade acetonitrile, methanol and analytical grade Milli-Q water, sodium hydroxide and glacial acetic acid were purchased from Merck. Water used was obtained by using Millipore MilliQ Plus water purification system. 
UPLC system (Waters, Milford, USA) consists of a binary solvent manager, a sample manager and a PDA detector. Empower 2 software was used to monitor the output signal. Cintex digital water bath was used for hydrolysis studies. Photo stability studies were carried out in a photo stability chamber (Sanyo, Leicestershire, UK). Thermal stability studies were performed in a dry air oven (Cintex, Mumbai, India).

Chromatographic conditions: The chromatographic column used was acquity $\mathrm{CSH} \mathrm{C}_{18} 100 \mathrm{~mm} \times 2.1 \mathrm{~mm}, 1.7 \mu \mathrm{m}$ particle size and separation was achieved on Isocratic method. Mobile phase contains mixture of Milli-Q water, acetonitrile and glacial acetic acid in the ratio of 50:50:1 (v/v), respectively. The flow rate and injection volume were $0.5 \mathrm{~mL} / \mathrm{min}$ and $2.0 \mu \mathrm{L}$, respectively. The column temperature was maintained at $30^{\circ} \mathrm{C}$ and the peaks were monitored at $260 \mathrm{~nm}$. A mixture of acetonitrile and water in the proportion of 90:10 (v/v) used as a diluent for sample preparation ${ }^{23-26}$.

Preparation of standard solution: A stock solution of naproxen $(630 \mu \mathrm{g} / \mathrm{mL})$ was prepared by dissolving an appropriate amount of drug in diluent. Standard solution of $7.5 \mu \mathrm{g} / \mathrm{mL}$ was prepared from the stock solution and used as diluted standard for determination of related substances. Mixed and individual stock solutions $(2.5 \mu \mathrm{g} / \mathrm{mL})$ of the impurities (Imp-A to Imp-D) were prepared in diluent and used for validation.

Preparation of sample solution: Crushed twenty tablets to a fine powder in mortar with pestle. Weighed accurately equivalent to $250 \mathrm{mg}$ crushed above powder into a $100 \mathrm{~mL}$ dried volumetric flask, add $75 \mathrm{~mL}$ of diluent, sonicate for 20 min with intermediate shaking and made up to volume with diluent $(2500 \mu \mathrm{g} / \mathrm{mL})$. The solution was filtered through a 0.22 $\mu \mathrm{m}$ nylon membrane filter and injected in UPLC.

Specificity: Specificity is the ability of the method to measure the analyte response in the presence of its potential impurities. Intentional degradation was attempted by the stress conditions of UV light $(254 \mathrm{~nm})$, heat $\left(105^{\circ} \mathrm{C}\right)$, acid $(1 \mathrm{~N}$ $\mathrm{HCL}$ at $\left.80{ }^{\circ} \mathrm{C}\right)$, base $\left(1 \mathrm{~N} \mathrm{NaOH}\right.$ at $\left.80{ }^{\circ} \mathrm{C}\right)$, hydrolytic $\left(90^{\circ} \mathrm{C}\right)$ and oxidation $\left(1.0 \% \mathrm{H}_{2} \mathrm{O}_{2}\right.$ at room temperature) to evaluate the ability of the proposed method to separate naproxen from its degradation and sumatriptan and its degradation products. For UV light exposure study time period was 10 days.

\section{RESULTS AND DISCUSSION}

Method development and optimization: The main objective of the research work is to separate degradation and process related impurities of sumatriptan and naproxen from naproxen. Simultaneous estimation was restricted due to different dosage strengths and different polarity nature and cross specificity. After thorough screening of different column stationary phases, organic modifiers, buffer $\mathrm{pH}$ and column oven temperatures, for accurate quantification of naproxen impurities and degradant in combination product, Isocratic method good separation was achieved within 10 min run time (Fig. 4). The separation was achieved by using Acquity $\mathrm{CSH}$ $\mathrm{C}_{18} 100 \mathrm{~mm} \times 2.1 \mathrm{~mm}, 1.7 \mu \mathrm{m}$ with $0.5 \mathrm{~mL} / \mathrm{min}$ flow rate. Good resolution was observed between naproxen and its impurities interference with excipients and sumatriptan, its impurities was also checked, one peak was observed at $0.6 \mathrm{~min}$, no interference observed at the retention times of impurity peaks and naproxen peak. Under optimized conditions naproxen and related impurities were well separated. The system suitability parameters were evaluated for naproxen and its four impurities (Table-1). The relative response factor for all the four impurities was determined with respect to naproxen (Fig. 1).
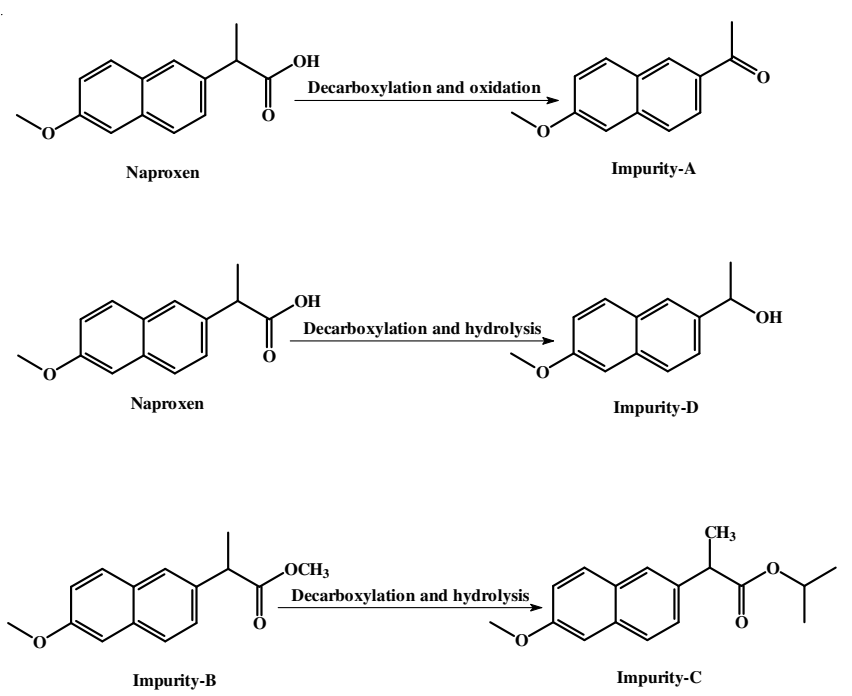

Fig. 1. Chemical structures, degradation pathway of naproxen and its related impurities

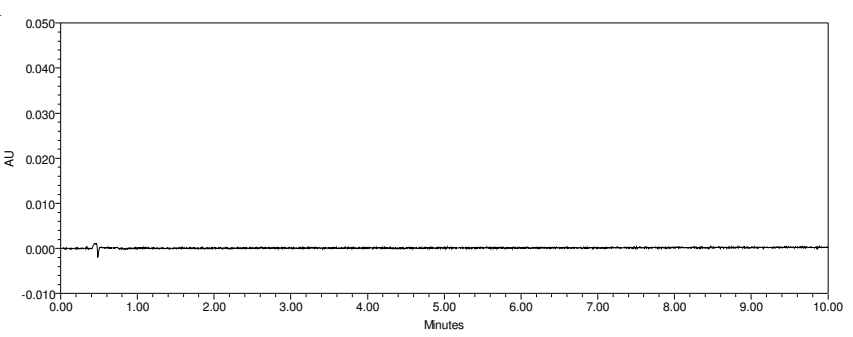

Fig. 2. Typical chromatogram of diluent

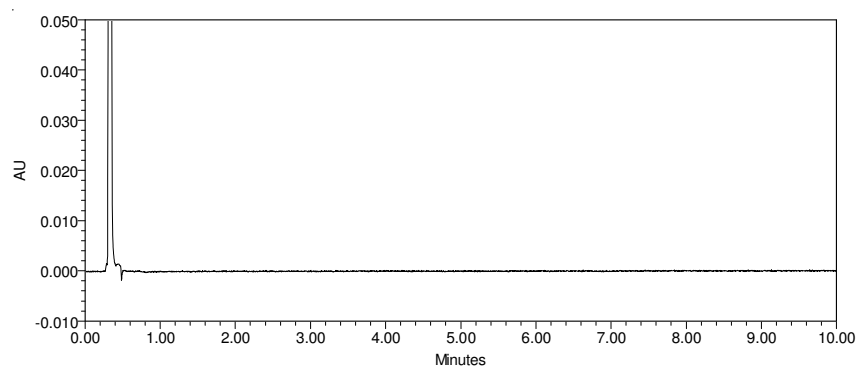

Fig. 3. Typical chromatogram of placebo

TABLE-1

SYSTEM SUITABILITY REPORT

\begin{tabular}{lcc}
\hline \multicolumn{1}{c}{ System suitability parameters } & $\begin{array}{c}\text { Observed } \\
\text { value }\end{array}$ & $\begin{array}{c}\text { Acceptance } \\
\text { limit }\end{array}$ \\
\hline $\begin{array}{l}\text { RSD of peak areas of naproxen } \\
\text { sodium from six replicate injection } \\
\text { of standard solution }\end{array}$ & 1.2 & NMT 10.0\% \\
$\begin{array}{l}\text { The tailing factor for naproxen } \\
\text { sodium peak in standard }\end{array}$ & 1.1 & NMT 2.0 \\
\hline
\end{tabular}

Validation of the method: After satisfactory development of the method it was subjected to method validation as 
per ICH guidelines ${ }^{27,28}$. The method was validated to demonstrate that it is suitable for its intended purpose by the standard procedure to evaluate adequate validation characteristics (accuracy, precision, linearity, robustness and stability indicating capability).

Precision: The precision is agreement between a series of measurements and proved by injecting six individual preparations of naproxen sample spiked with $0.10 \%$ of its four impurities $(0.1 \%$ of impurities with respect to $2500 \mu \mathrm{g} / \mathrm{mL}$ naproxen). The intermediate precision of the method was also evaluated using different analyst and different instrument (Waters Acquity UPLC ${ }^{\mathrm{TM}}$ system with tunable ultraviolet detector, Milford, USA) and performing the analysis on different day. \% RSD of area count of each impurity was calculated for both precision as well as intermediate precision and was found within $2 \%$. These results confirmed the precision and ruggedness of the method (Table-2).

Accuracy: The accuracy is an agreement between the measured and real value. Three different concentration levels of solutions prepared in triplicate $(0.15,0.3$ and $0.45 \%)$ of the test concentration $(2500 \mu \mathrm{g} / \mathrm{mL})$ and injected into the UPLC. The calculated recovery of all the impurities and naproxen ranged from 93.5 to $105.6 \%$. The results are given in Table-3.

Limit of detection and quantification: Limit of detection and limit of quantification for and naproxen and its related compounds were estimated as the concentrations for which signal-to-noise ratios were 3:1 and 10:1, respectively. Dilute solutions of known concentrations were injected and calculated the signal to noise ratio, selected the concentration of the solution for which the signal to noise ratio was 3,10 as LOD and LOQ. Precision was also determined at the LOQ level by analysis of six individual preparations of the four impurities and calculating the RSD (\%) of the peak area for each impurity. The determined LOD, LOQ and precision at LOQ values are reported in Table-4.

Linearity: Solutions for linearity testing were prepared by diluting the impurity stock solution to five different concentrations from LOQ to $200 \%$ of the permitted maximum level of the impurity (i.e., the LOQ to $0.2 \%$ for naproxen and its impurities). The correlation coefficients, slopes and y intercepts of the calibration plots are reported. Calibration plots for the four related substances were linear over the ranges tested. The correlation coefficients were $>0.998$ for all the components

TABLE-2

PRECISION DATA OF NAPROXEN AND ITS IMPURITIES

\begin{tabular}{ccccccccc}
\hline & \multicolumn{7}{c}{ Naproxen sodium Impurities } \\
\cline { 2 - 9 } Sample No. & \multicolumn{2}{c}{ Impurity-A } & \multicolumn{2}{c}{ Impurity-B } & \multicolumn{2}{c}{ Impurity-C } & \multicolumn{2}{c}{ Impurity-D } \\
\cline { 2 - 9 } & RRT & Impurity (\%) & RRT & Impurity (\%) & RRT & Impurity (\%) & RRT & Impurity (\%) \\
\hline 1 & 1.33 & 0.133 & 2.2 & 0.149 & 4.49 & 0.13 & 0.84 & 0.123 \\
2 & 1.33 & 0.133 & 2.2 & 0.146 & 4.49 & 0.102 & 0.84 & 0.127 \\
3 & 1.33 & 0.133 & 2.2 & 0.148 & 4.49 & 0.124 & 0.84 & 0.125 \\
4 & 1.33 & 0.134 & 2.21 & 0.149 & 4.50 & 0.109 & 0.84 & 0.136 \\
5 & 1.33 & 0.131 & 2.21 & 0.149 & 4.50 & 0.111 & 0.84 & 0.123 \\
6 & 1.33 & 0.132 & 2.21 & 0.150 & 4.51 & 0.115 & 0.84 & 0.122 \\
AVG & - & 0.133 & - & 0.149 & - & 0.115 & - & 0.126 \\
RSD (\%) & - & 0.800 & - & 0.900 & - & 8.900 & - & 4.100 \\
\hline
\end{tabular}

TABLE-3

ACCURACY DATA OF NAPROXEN AND ITS IMPURITIES

\begin{tabular}{|c|c|c|c|c|c|c|c|c|}
\hline \multirow{3}{*}{ Sample No. } & \multicolumn{4}{|c|}{ Impurity-A } & \multicolumn{4}{|c|}{ Impurity-B } \\
\hline & \multirow{2}{*}{$\begin{array}{l}\text { Spike level } \\
(\%)\end{array}$} & \multirow{2}{*}{$\begin{array}{l}\text { Added } \\
(\mu \mathrm{g} / \mathrm{mL})\end{array}$} & $\begin{array}{c}\text { Found } \\
(\mu \mathrm{g} / \mathrm{mL})\end{array}$ & \multirow{2}{*}{$\begin{array}{c}\text { Mean } \\
\text { recovery }(\%)\end{array}$} & \multirow{2}{*}{$\begin{array}{c}\text { Spike level } \\
(\%)\end{array}$} & \multirow{2}{*}{$\begin{array}{c}\text { Added } \\
(\mu \mathrm{g} / \mathrm{mL})\end{array}$} & $\begin{array}{c}\text { Found } \\
(\mu \mathrm{g} / \mathrm{mL})\end{array}$ & \multirow{2}{*}{$\begin{array}{c}\text { Mean } \\
\text { recovery }(\%)\end{array}$} \\
\hline & & & (Recovered) & & & & (Recovered) & \\
\hline 1 & 40 & 1.0088 & 0.875 & 86.7 & 40 & 0.9973 & 1.050 & 105.63 \\
\hline 2 & 75 & 1.8915 & 2.150 & 113.7 & 75 & 1.8699 & 2.100 & 111.40 \\
\hline 3 & 100 & 2.5220 & 2.900 & 114.0 & 100 & 2.4933 & 2.675 & 105.63 \\
\hline 4 & 125 & 3.1525 & 3.600 & 113.1 & 125 & 3.1166 & 3.450 & 112.10 \\
\hline \multirow[t]{2}{*}{5} & 150 & 3.7830 & 4.300 & 112.5 & 150 & 3.7399 & 4.125 & 111.00 \\
\hline & \multicolumn{4}{|c|}{ Impurity-C } & \multicolumn{4}{|c|}{ Impurity-D } \\
\hline 1 & 40 & 0.9986 & 0.95 & 95.10 & 40 & 1.0050 & 0.925 & 92.00 \\
\hline 2 & 75 & 1.8724 & 1.11 & 91.66 & 75 & 1.8844 & 2.125 & 112.80 \\
\hline 3 & 100 & 2.4965 & 2.42 & 94.43 & 100 & 2.5125 & 2.875 & 111.40 \\
\hline 4 & 125 & 3.1207 & 4.30 & 102.70 & 125 & 3.1400 & 3.525 & 111.16 \\
\hline 5 & 150 & 3.7429 & 4.30 & 102.60 & 150 & 3.7688 & 4.150 & 110.10 \\
\hline \multicolumn{9}{|c|}{ Naproxen sodium } \\
\hline \multicolumn{2}{|c|}{ Sample No. } & \multicolumn{2}{|c|}{ Spike level (\%) } & Added $(\mu \mathrm{g} / \mathrm{mL})$ & \multicolumn{2}{|c|}{$\begin{array}{c}\text { Found }(\mu \mathrm{g} / \mathrm{mL}) \\
\text { (Recovered) }\end{array}$} & \multicolumn{2}{|c|}{ Mean recovery $(\%)$} \\
\hline \multicolumn{2}{|c|}{1} & \multirow{2}{*}{\multicolumn{2}{|c|}{$\begin{array}{l}30 \\
75\end{array}$}} & 2.2837 & \multicolumn{2}{|c|}{2.375} & \multicolumn{2}{|c|}{103.6} \\
\hline \multicolumn{2}{|c|}{2} & & & 5.7854 & \multicolumn{2}{|r|}{5.775} & \multicolumn{2}{|r|}{99.4} \\
\hline \multicolumn{2}{|c|}{3} & \multicolumn{2}{|c|}{$\begin{array}{c}75 \\
100\end{array}$} & 7.6124 & \multicolumn{2}{|r|}{7.575} & \multicolumn{2}{|r|}{99.3} \\
\hline \multicolumn{2}{|c|}{1} & \multicolumn{2}{|c|}{125} & 9.5916 & & 9.425 & & 97.8 \\
\hline 2 & & 150 & & 11.4186 & & 1.300 & & 98.2 \\
\hline
\end{tabular}


TABLE-4

LIMIT OF DETECTION AND LIMIT OF QUANTIFICATION OF NAPROXEN AND ITS IMPURITIES

\begin{tabular}{lcccccc}
\hline \multirow{2}{*}{ Name } & \multicolumn{2}{c}{ Impurity (\%) } & \multicolumn{2}{c}{ LOQ Accuracy (n3) } & \multicolumn{2}{c}{ Signal to noise ratio } \\
\cline { 2 - 7 } & Limit of detection & Limit of quantification & Mean & RSD (\%) & LOD & LOQ \\
\hline Impurity-A & 0.00033 & 0.002 & 0.002 & 0 & 3 & 10 \\
Impurity-B & 0.005 & 0.017 & 0.017 & 0 & 3 & 10 \\
Impurity-C & 0.011 & 0.032 & 0.032 & 1.3 & 3 & 10 \\
Impurity-D & 0.001 & 0.006 & 0.006 & 0 & 3 & 10 \\
Naproxen sodium & 0.002 & 0.007 & 0.007 & 7 & 3 & 10 \\
\hline
\end{tabular}

(Table-5). These results show there was an excellent correlation between the peak area and concentration for the four impurities.

\begin{tabular}{lccc}
\multicolumn{5}{c}{ TABLE-5 } \\
LINEARITY \\
\hline Name of impurity & $\begin{array}{c}\text { Coefficient of } \\
\text { regression }(\mathrm{m})\end{array}$ & $\begin{array}{c}\text { Constant of } \\
\text { regression }(\mathrm{b})\end{array}$ & $\begin{array}{c}\text { Coefficient of } \\
\text { correlation }(\mathrm{r})\end{array}$ \\
\hline Impurity-A & 73499.3823 & 3309.097769 & 0.99982 \\
Impurity-B & 11100.9593 & 780.511935 & 0.99972 \\
Impurity-C & 10209.3750 & 438.261258 & 0.99897 \\
Impurity-D & 13086.6030 & 925.793832 & 0.99904 \\
Naproxen sodium & 10638.1663 & 1065.067617 & 0.99979 \\
\hline
\end{tabular}

Robustness: To determine the robustness, is a measure of method capacity to remain unaffected by small, but deliberate changes in the chromatographic conditions. To prove the robustness of the test method flow rate was changed to 0.48 and $0.52 \mathrm{~mL} \mathrm{~min}^{-1}$, column temperature was changed to 25 and $35^{\circ} \mathrm{C}$. In all these experiments the mobile phase components were not changed. The effect of the per cent organic strength on resolution was studied by varying acetonitrile by -10 to $+10 \%$, while other mobile phase components were held constant. In all the deliberate varied chromatographic conditions the selectivity as well as the performance of the method was unchanged proves the robustness of the method.

Solution stability and mobile phase stability: Solution stability was established by injecting the same standard and spiked sample at the time intervals of 0,24 and $48 \mathrm{~h}$, standard and spiked sample solution kept on bench top during the study. Mobile phase stability was established by injecting the freshly prepared standard and spiked sample at the time intervals of 0,24 and $48 \mathrm{~h}$, without changing the mobile phase lot. The difference between percentage of individual impurity and total impurities at 0,24 and $48 \mathrm{~h}$ time intervals were less than
0.05 and $0.1 \%$. The results confirmed that standard solution, sample solution and mobile phase were stable up to $48 \mathrm{~h}$.

Specificity: The stress study samples were analyzed using PDA detector to monitor the homogeneity and purity of the naproxen peak. Degradation was not observed when naproxen was subjected to light, base, hydrolysis and heat conditions. Significant degradation was observed when the drug was subjected to peroxide $\left(0.1 \mathrm{~N} \mathrm{HCl}\right.$ at $80{ }^{\circ} \mathrm{C}$ for $\left.1 \mathrm{~h}\right)$, leading to the formation of Imp-A and oxidative hydrolysis $\left(1.0 \% \mathrm{H}_{2} \mathrm{O}_{2}\right.$ at room temperature for $5 \mathrm{~h}$ ) (Fig. 1), leading to the formation of Imp-A and Imp-D. Acid and peroxide force degradation studies are shown in Figs. 7-10. The results from the forced degradation studies are presented in Table-6. Assay of stressed samples has been performed by comparison with reference standard and the mass balance (assay $\%+$ impurities $\%+$ degradation $\%$ products) were calculated. Specificity results were presented in Table-6 and Figs. 2-10.

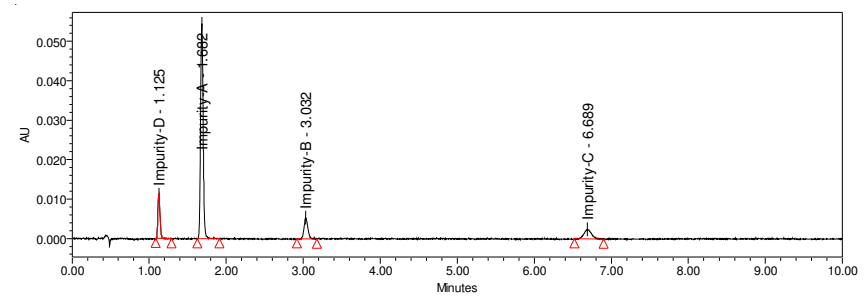

Fig. 4. Typical chromatogram of impurities blend solution

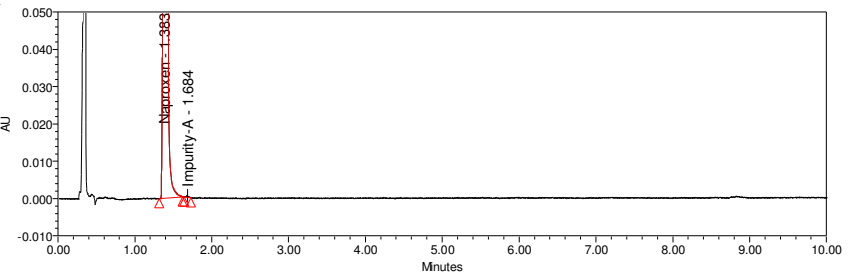

Fig. 5. Typical chromatogram of sample

TABLE-6

SUMMARY OF FORCED DEGRADATION STUDY

\begin{tabular}{|c|c|c|c|c|}
\hline \multirow{2}{*}{ Stress condition } & \multicolumn{4}{|c|}{ Drug product } \\
\hline & Degradation $(\%)$ & Purity angle & Purity threshold & Purity flag \\
\hline $\begin{array}{l}\text { Refluxed with } 1 \mathrm{~N} \mathrm{HCl} \text { solution for } c a 1 \mathrm{~h} \text { at } 80^{\circ} \mathrm{C} \text { and neutralized with } 1 \\
\mathrm{~N} \mathrm{NaOH}\end{array}$ & 2.09 & 7.028 & 7.486 & No \\
\hline $\begin{array}{l}\text { Refluxed with } 1 \mathrm{~N} \mathrm{NaOH} \text { solution for about } 2 \mathrm{~h} \text { at } 80^{\circ} \mathrm{C} \text { and neutralized } \\
\text { with } 1 \mathrm{~N} \mathrm{HCl}\end{array}$ & ND & 12.375 & 90 & No \\
\hline Treated with $1 \%$ hydrogen peroxide $\left(\mathrm{H}_{2} \mathrm{O}_{2}\right)$ for $5 \mathrm{~h}$ at room temperature & 12 & 12.162 & 87.805 & No \\
\hline Refluxed with purified water for $6 \mathrm{~h}$ at $100{ }^{\circ} \mathrm{C}$ & 2.5 & 13.289 & 26.868 & No \\
\hline Exposed to sunlight for 1.2 million lux hours & 0.5 & 13.358 & 90 & No \\
\hline $\begin{array}{l}\text { Exposed to UV light both at shorter and longer wavelengths for } 200 \text { watt } \\
\text { hours/square meter }\end{array}$ & 2.45 & 13.481 & 90 & No \\
\hline Dry heating done at $105^{\circ} \mathrm{C}$ for $12 \mathrm{~h}$ & 0.07 & 13.852 & 17.378 & No \\
\hline Exposed to humidity at $25^{\circ} \mathrm{C}, 90 \% \mathrm{RH}$ for 7 days & 0.06 & 12.892 & 55.024 & No \\
\hline
\end{tabular}




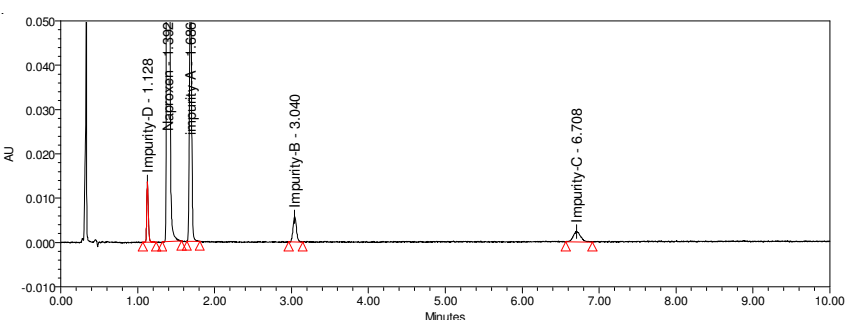

Fig. 6. Typical chromatogram impurity spiked on sample

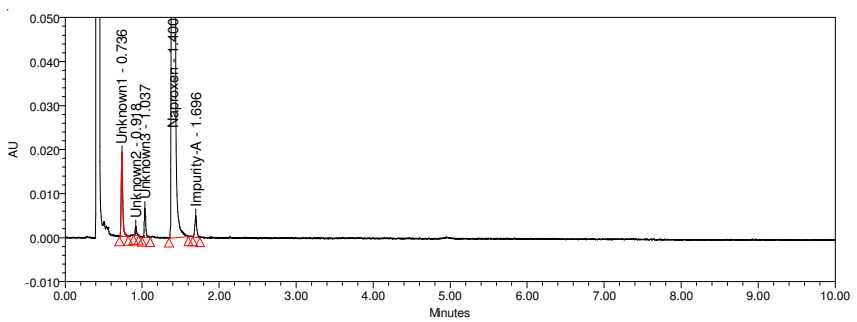

Fig. 7. Typical chromatogram of acid degradation

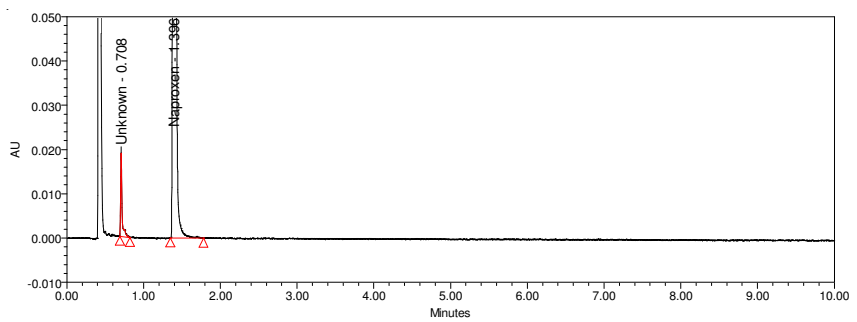

Fig. 8. Typical chromatogram of base degradation

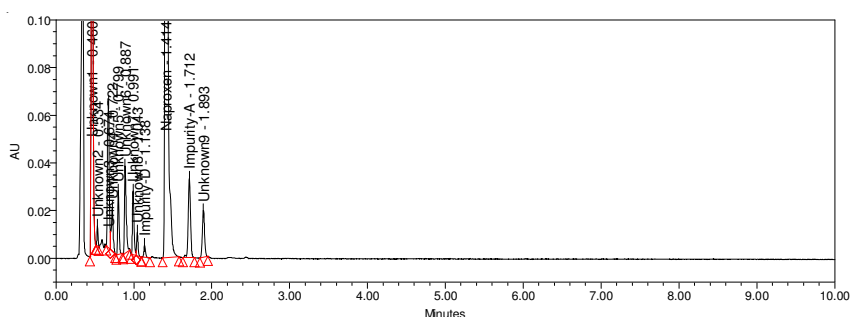

Fig. 9. Typical chromatogram of oxidation degradation

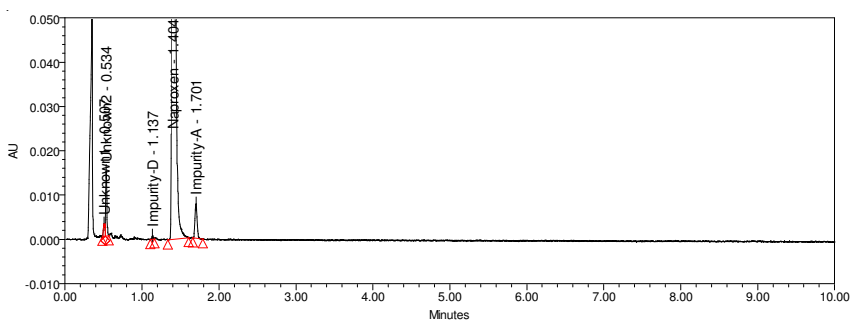

Fig. 10. Typical chromatogram of water hydrolysis degradation

\section{Conclusion}

A novel UPLC method was successfully developed and validated for the determination of process related and degradation impurities in naproxen in combination dosage forms. Method validation results have proved the method to be selective, precise, accurate and robust and stability indicating. The total runtime was $10 \mathrm{~min}$ with in which all the impurities were well resolved from naproxen. This method can be successfully applied for the routine analysis as well as stability study.

\section{ACKNOWLEDGEMENTS}

The authors thank the management of Dr. Reddy's Laboratories Ltd. for supporting this work. Cooperation from colleagues of Research \& Development and Analytical Research \& Development of Dr. Reddy's Laboratories Ltd. is also appreciated.

\section{REFERENCES}

1. E.J. Segre, J. Reprod. Med., 25, 222 (1980).

2. V. Bansal, T. Dex, H. Proskin and S. Garreffa, J. Clin. Pharmacol., 41, 127 (2001).

3. P. Di Martino, C. Barthelemy, E. Joiris, D. Capsoni, A. Masic, V. Massarotti, R. Gobetto, M. Bini and S. Martelli, J. Pharm. Sci., 96, 156 (2007).

4. S. Moyer, Cephalalgia, 6, 77 (1986).

5. J.J. Li, M.B. Norton, E.J. Reinhard, G.D. Anderson, S.A. Gregory, P.C. Isakson, C.M. Koboldt, J.L. Masferrer, W.E. Perkins, K. Seibert, Y. Zhang, B.S. Zweifel and D.B. Reitz, J. Med. Chem., 39, 1846 (1996).

6. E.J. Segre, J. Reprod. Med., 25S, 222 (1980).

7. R.D. Toothaker, S.H. Barker, M.V. Gillen, S.A. Helsinger, C.G. Kindberg, T.L. Hunt and J.H. Powell, Biopharm. Drug Dispos., 21, 229 (2000).

8. G. Kanoute, E. Nivaud, B. Paulet and P. Boucly, Talanta, 31, 144 (1984).

9. M.S. Mahrous, M.M. Abdel-Khakel and M.E. Abdel-Mamid, J. Assoc. Off. Anal. Chem., 68, 535 (1985).

10. S. Kulsum, M. Padmalatha, K. Sandeep, B. Saptasila and G. Vidyasagar, Int. J. Res. Pharm. Biomed. Sci., 2, 1303 (2011).

11. R.P. Gondalia and A.P. Dharamsi, Int. J. Res. Pharm. Biomed. Sci., 1, 24 (2010).

12. T. Haque, M.U. Talukder, S.L. Fatema and A.K.L. Kabir, Stamford J. Pharm. Sci., 1, 18 (2008).

13. A.S. Carretero, C.C. Blanco, M.I.R. Garcia, B.C. Diaz and F.G. Alberto, Talanta, 50, 401 (1999).

14. J.W. Wainer and T.D. Doyle, J. Chromatogr., 284, 117 (1984).

15. R. Kumar, P. Singh and H. Singh, Int. J. Pharm. Res. Develop., 12, 227 (2011).

16. Y.H. Hsu, Y.B. Liou, J.A. Lee, C.Y. Chen and A.B. Wu, Biomed. Chromatogr., 20, 787 (2006).

17. Y.-J. Xu, Determination of Related Substances in Compound Naproxen Suppositories by RP-HPLC, Central South Pharmacy 05 (2005).

18. L. Monser and F. Darghouth, J. Pharm. Biomed. Anal., 32, 1087 (2003).

19. W.R.G. Baeyens, G. Weken and M. Schelkens, J. Fluorescence, 5, 131 (1995).

20. M. Trinath, S.K. Banerjee, D.H.H. Teja and C.G. Bonde, Der Pharm. Sinica, 1, 36 (2010).

21. R.P. Gondalia and A.D. Dharamsi, Asian J. Pharm. Clin. Res., 4, 31 (2011).

22. R. Gondalia and A. Dharamsi, Int. J. Pharm. Sci. Res., 2, 116 (2011).

23. Z. Ge, E. Tessier, L. Neirinck and Z. Zhu, J. Chromatogr. B, 806, 299 (2004).

24. X. Xu, M.G. Bartlett and J.T. Stewart, J. Pharm. Biomed. Anal., 26, 367 (2001).

25. K.N. Cheng, M.J. Redrup, A. Barrow and P.N. Williams, J. Pharm. Biomed. Anal., 17, 399 (1998).

26. D.W. Boulton, G.F. Duncan and N.N. Vachharajani, Biomed. Chromatogr, 17, 48 (2003).

27. ICH, Stability Testing of New Drug Substances and Products (Q1AR): International Conference on Harmonization, IFPMA, Geneva (2000).

28. ICH, Validation of Analytical Procedures: Text and Methodology (Q 2(R1)): International Conference on Harmonization, IFPMA, Geneva (2005). 